\title{
A Study of the Clinical Significance of Lipoprotein (a) in Nephrotic Syndrome
}

\author{
Tadayoshi TAKEgoshI, Chikashi KITOH, Toshihiro HABA, \\ Jun-ichi HIRAI, Takanobu WAKASUGI, Takashi SAGA, \\ Yoshikiyo YAMAZAKI and Hiroshi MABUCHI*
}

\begin{abstract}
Lipoprotein $(\mathrm{Lp})($ a) concentrations were measured in eight patients with nephrotic syndrome in the age range of 8 to $69 \mathrm{yrs}$. Mean $( \pm S E)$ levels of serum $L p(a)$ were elevated in the nephrotic patients compared to controls $(76.5 \pm 19.7 \mathrm{vs} 18.6 \pm 0.9 \mathrm{mg} / \mathrm{dl}, \mathrm{p}<0.001)$. After treatment with prednisolone, $\mathrm{Lp}(\mathrm{a})$ concentrations were decreased from $85.2 \pm 21.6$ to $42.2 \pm 14.0 \mathrm{mg} / \mathrm{dl}$. During the treatment, serum total cholesterol showed a negative correlation with serum albumin concentration. However, no correlation was noted between $\operatorname{Lp}(a)$ and serum albumin concentration. There were no significant correlations between $L p(a)$ and other lipoprotein lipid and apolipoprotein levels. It was concluded that hyperLp(a) aemia may be an independent risk factor in the development of premature atherosclerosis in patients with nephrotic syndrome.
\end{abstract}

Key words: Atherosclerosis, HyperLp(a)aemia

Lipoprotein(a)[Lp(a)] level is known to be elevated in patients with ischemic heart disease (IHD). Although the pathogenesis of arteriosclerotic changes in patients with nephrotic syndrome remains to be elucidated, hyperlipoproteinemia associated with nephrotic syndrome and corticosteroid therapy may, in part, play an important role in the development of premature atherosclerosis. The authors recently reported a case of nephrotic syndrome presenting hyperLp(a)aemia accompanied by myocardial infarction and cerebral infarction in a case of systemic lupus erythematosus (1). In the present study, serum $\mathrm{Lp}$ (a) concentrations were determined in order to investigate any abnormalities of lipoprotein metabolism in patients with nephrotic syndrome.

\section{SUBJECTS AND METHODS}

Subjects were twelve previously untreated patients with nephrotic syndrome (8 males and 4 females, average age $31 \pm 13$ yrs), who have been under treatment and hospitalized in our hospital. Healthy normal subjects were used for comparison. Renal biopsy specimens were determined by light microscopy and a fluorescent antibody method (Table 1). Fasting blood samples were drawn for serum lipoprotein analysis. According to the method of Havel et al (2), lipoprotein was separated into very low density lipoproteins (VLDL), intermediate (IDL), low (LDL) and high (HDL) density lipoproteins by preparative ultracentrifugation at densities of $1.006,1.019,1.063 \mathrm{~g} / \mathrm{ml}$ using a Hitachi model 55p-7 Ultracentrifuge (Hitachi Koki Co., Tokyo, Japan). Cholesterol (TC) and triglyceride (TG) concentrations in serum and each fraction of lipoprotein were determined by an enzymatic method using a commercially available kit (Kyowa Medex Co., Tokyo, Japan). Lipoprotein electrophoresis was performed by means of $1 \%$ agarose film using tricine-lithium buffer $(\mathrm{pH} 8.6)$ and disc

From The Department of Internal Medicine, Fukui Prefectural Hospital, Fukui and *The Second Department of Internal Medicine, School of Medicine, Kanazawa University, Kanazawa

Received for publication December 21, 1989; Accepted for publication September 18, 1990

Reprint requests should be addressed to Tadayoshi Takegoshi, MD, Department of Internal Medicine,

Fukui Prefectural Hospital, 8-1-2 Yotsui, Fukui 910, Japan 
Table 1. Clinical characteristics of 12 untreated patients with nephrotic syndrome.

\begin{tabular}{|c|c|c|c|c|c|c|c|c|c|c|c|c|c|c|c|}
\hline No. & Case & $\begin{array}{l}\text { Age } \\
(y r)\end{array}$ & $\begin{array}{l}\text { Sex } \\
(F / M)\end{array}$ & $\begin{array}{l}\mathrm{Ht} \\
(\mathrm{cm})\end{array}$ & $\begin{array}{l}\text { Wt } \\
(\mathrm{kg})\end{array}$ & $\begin{array}{l}\text { Percent of } \\
\text { ideal body } \\
\text { weight }\end{array}$ & $\begin{array}{l}\text { Choles- } \\
\text { terol } \\
(\mathrm{mg} / \mathrm{dl})\end{array}$ & $\begin{array}{l}\text { Trigly- } \\
\text { ceride } \\
(\mathrm{mg} / \mathrm{dl})\end{array}$ & $\begin{array}{l}\mathrm{Lp}(\mathrm{a}) \\
(\mathrm{mg} / \mathrm{dl})\end{array}$ & $\begin{array}{l}\text { ApoB } \\
(\mathrm{mg} / \mathrm{dl})\end{array}$ & $\begin{array}{l}\text { Total } \\
\text { protein } \\
(\mathrm{g} / \mathrm{dl})\end{array}$ & $\begin{array}{l}\text { Albumin } \\
(\mathrm{g} / \mathrm{dl})\end{array}$ & $\begin{array}{l}\text { BUN } \\
(\mathrm{mg} / \mathrm{dl})\end{array}$ & $\begin{array}{l}\text { Creati- } \\
\text { nine } \\
(\mathrm{mg} / \mathrm{dl})\end{array}$ & Renal biopsy* \\
\hline 1) & & 42 & $\mathbf{M}$ & 164 & 70 & 120 & 644 & 262 & 221 & & 5.3 & 2.0 & 11 & 0.9 & - \\
\hline 2) & & 27 & $M$ & 167 & 61 & 107 & 239 & 105 & 13 & & 4.6 & 1.7 & 12 & 1.2 & Minimal change \\
\hline 3) & & 22 & $\mathbf{M}$ & 175 & 66 & 102 & 454 & 201 & 67 & & 4.7 & 2.1 & 23 & 1.1 & Minimal change \\
\hline 4) & & 28 & $\mathrm{~F}$ & 142 & 47 & 112 & 448 & & 63 & & 4.1 & 1.6 & 23 & 1.1 & Lupus nephritis \\
\hline 5) & & 21 & M & 163 & 60 & 103 & 309 & 179 & 197 & 296 & 6.6 & & 11 & 0.9 & Lupus nephritis \\
\hline 6$)$ & & 23 & $\mathbf{M}$ & 180 & 66 & 94 & 357 & 179 & 28 & 127 & 4.7 & 1.8 & 43 & 1.0 & Minimal change \\
\hline 7) & & 8 & $M$ & 128 & 25 & 89 & 634 & 334 & 29 & & 4.6 & 1.4 & 18 & 0.8 & - \\
\hline 8) & & 69 & $\mathrm{~F}$ & 140 & 40 & 100 & 337 & 259 & 18 & 157 & 5.5 & 2.6 & 14 & 1.3 & - \\
\hline 9) & & 50 & $\mathbf{M}$ & 150 & 53 & 94 & 652 & 266 & 64 & 236 & 3.3 & 1.8 & 123 & 2.7 & Minimal change \\
\hline 10) & & 50 & $\mathrm{~F}$ & 160 & 54 & 98 & 239 & 180 & 140 & 158 & 7.6 & 3.0 & 17 & 0.9 & Lupus nephritis \\
\hline 11) & & 14 & $\mathrm{~F}$ & 145 & 39 & 87 & 293 & 147 & 59 & 111 & & & 27 & 1.4 & Focal GN \\
\hline 12) & & 17 & $\mathrm{M}$ & 171 & 44 & 72 & 287 & 301 & 19 & 125 & 5.3 & 3.4 & 40 & 1.8 & Lupus nephritis \\
\hline Mean & & 31 & & 157 & 52 & 98 & 408 & 219 & 77 & 172 & 5.1 & 2.1 & 30 & 1.3 & \\
\hline $\mathrm{SD}$ & & 17 & & 15 & 13 & 12 & 151 & 67 & 68 & 63 & 1.1 & 0.6 & 30 & 0.5 & \\
\hline
\end{tabular}

* Focal GN, focal glomerulonephritis

electrophoresis was performed using $3.6 \%$ polyacrylamide gels as described by Narayan et al (3). The concentrations of serum apolipoprotein were measured by single radial immunodiffusion using plates obtained from Daiichi Kagaku Co., Tokyo, Japan (4). Quantitation of $\mathrm{Lp}(\mathrm{a})$ was determined using a single radial immunodiffusion method in which $1 \%$ agarose (PH 8.6, Agarose immunodiffusion tablets, Bio-rad, Richmond, Virginia) containing $1 \% \mathrm{Lp}(\mathrm{a})$ antiserum was used (5). The courses of 8 cases could be followed up with the collection of blood samples being performed after an improvement of serum protein level and the disappearance of urine protein or its diminution to less than $0.5 \mathrm{~g} /$ day. Informed concent was obtained from all individuals prior to beginning the study.

\section{RESULTS}

Table 2 shows TC and TG values of lipoprotein for all healthy normal subjects and untreated patients with nephrotic syndrome, before and after treatment. TC and TG in whole serum, VLDL, IDL, LDL and HDL before treatment showed significantly higher values than the controls, as was the same as TC in whole serum, LDL and HDL and as TG in whole serum, IDL, LDL and HDL after treatment. As far as the nephrotic syndrome as a whole was concerned, $\mathrm{Lp}$ (a) showed significantly higher values, $76.5 \pm 19.7 \mathrm{mg} / \mathrm{dl}$ compared with $18.6 \pm 0.9 \mathrm{mg} / \mathrm{dl}$, for healthy normal subjects (mean \pm SE) (Fig. 1). In the comparison of between before and after treatment with prednisolone, TC

Table 2. Serum lipid, lipoprotein, apoprotein B and $L p(a)$ levels in patients with nephrotic syndrome before and after treatment with prednisolone.

\begin{tabular}{|c|c|c|c|c|c|c|c|c|c|c|c|c|c|}
\hline & \multirow[b]{2}{*}{$\mathrm{n}$} & \multicolumn{5}{|c|}{ Cholesterol (mg/dl) } & \multicolumn{5}{|c|}{ Triglyceride $(\mathrm{mg} / \mathrm{dl})$} & $\mathrm{Lp}(\mathrm{a})$ & \multirow[t]{2}{*}{ Apo B } \\
\hline & & Total & VLDL & IDL & LDL & $\mathrm{HDL}$ & Total & VLDL & IDL & LDL & $\mathrm{HDL}$ & (mg & \\
\hline $\begin{array}{l}\text { Before } \\
\text { treatment }\end{array}$ & 8 & $459 \pm 159^{\#}$ & $30 \pm 3^{\#}$ & $22 \pm 18^{\#}$ & $267 \pm 120^{\#}$ & $90 \pm 37^{\#}$ & $218 \pm 67^{\sharp}$ & $82 \pm 54^{*}$ & $25 \pm 14^{\#}$ & $68 \pm 37^{*}$ & $25 \pm 11^{\#}$ & $85 \pm 26$ & $172 \pm 63$ \\
\hline $\begin{array}{l}\text { After } \\
\text { treatment }\end{array}$ & 8 & $243 \pm 43^{\#}$ & $17 \pm 8$ & $11 \pm 4$ & $138 \pm 28^{\#}$ & $84 \pm 22^{\#}$ & $130 \pm 82^{\#}$ & $60 \pm 69$ & $19 \pm 15^{\#}$ & $30 \pm 14^{\#}$ & $21 \pm 4^{\#}$ & $42 \pm 14$ & $115 \pm 18$ \\
\hline $\begin{array}{l}\text { Normal } \\
\text { subjects }\end{array}$ & 20 & $183 \pm 28$ & $14 \pm 7$ & $6 \pm 3$ & $98 \pm 23$ & $48 \pm 73$ & $89 \pm 32$ & $42 \pm 24$ & $6 \pm 3$ & $17 \pm 6$ & $15 \pm 3$ & $18 \pm 10$ & $96 \pm 5$ \\
\hline
\end{tabular}

All values are mean $\pm \mathrm{SD} . \quad * \mathrm{p}<0.02, \# \mathrm{p}<0.001$ compared with normal subjects. 


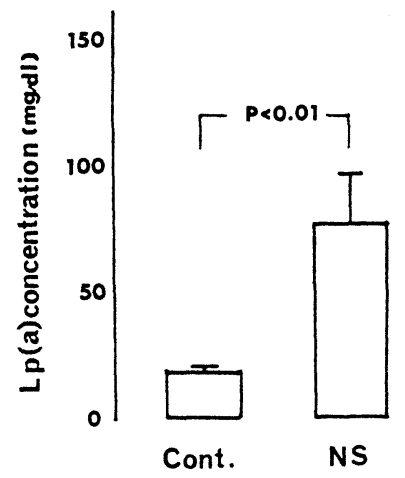

Fig. 1. Mean $( \pm S E)$ levels of $\mathrm{Lp}$ (a) in normal controls and nephrotic patients (NS).
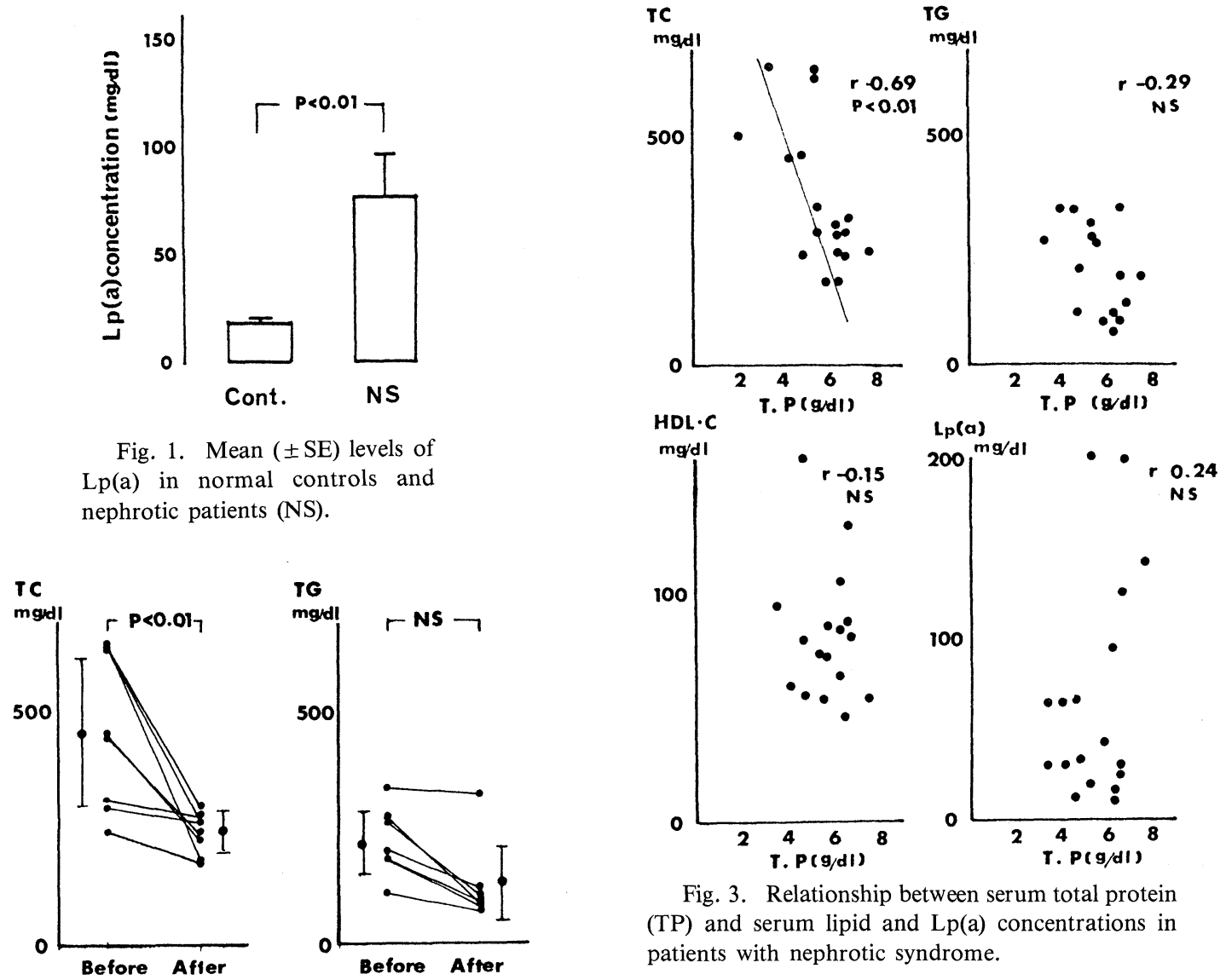

Fig. 3. Relationship between serum total protein (TP) and serum lipid and Lp(a) concentrations in patients with nephrotic syndrome.

relationship of serum lipid levels before and after treatment; TC and serum protein showed a significant negative correlation, but neither correlation was noted among TG, HDL-C, apo B and Lp(a). No significant correlation was noted with BUN, creatinine, dose of steroid, morbid period, age, proteinuria, blood pressure or body wt.

\section{DISCUSSION}

$\mathrm{Lp}$ (a)lipoprotein was first described in 1963 as a genetic variant of beta lipoprotein which is inherited as an autosomal dominant trait (6). Many studies have been conducted on the relationship of $\mathrm{Lp}(\mathrm{a})$ with ischemic heart disease from 1970 (7-13). Through protein sequencing and cDNA cloning, McLean et al reported that apo(a) is very similar to human plasminogen, the precursor of the proteolytic enzyme plasmin which dissolves fibrin clots (14). Recent studies have suggested that the competition of $\mathrm{Lp}(\mathrm{a})$ and plasminogen for cellular 
Table 3. Correlation coefficients between $\mathrm{Lp}(\mathrm{a})$ and serum lipoprotein and apo B levels in patients with nephrotic syndrome.

\begin{tabular}{lcc}
\hline Variables* $^{*}$ & $\mathrm{r}$ & p value $^{\#}$ \\
\hline TC & 0.33 & $\mathrm{NS}$ \\
VLDL-C & 0.09 & $\mathrm{NS}$ \\
IDL-C & 0.32 & $\mathrm{NS}$ \\
LDL-C & 0.28 & $\mathrm{NS}$ \\
HDL-C & 0.21 & $\mathrm{NS}$ \\
LDL-C/HDL-C & 0.18 & $\mathrm{NS}$ \\
TG & -0.03 & $\mathrm{NS}$ \\
VLDL-TG & -0.24 & $\mathrm{NS}$ \\
IDL-TG & 0.14 & $\mathrm{NS}$ \\
LDL-TG & 0.37 & $\mathrm{NS}$ \\
HDL-TG & 0.11 & $\mathrm{NS}$ \\
Apo B & 0.36 & NS \\
\hline
\end{tabular}

* TC, total cholesterol; TG, triglyceride; VLDL, very-low density lipoprotein; IDL, intermediatedensity lipoprotein; LDL, low-density lipoprotein; HDL, high-density lipoprotein.

\# NS, not significant.

binding sites might contribute to the thrombotic and atherosclerotic risks associated with elevated $\mathrm{Lp}(\mathrm{a})$ levels (15). According to Kawade (16), 70\% of healthy normal subjects show $L p(a)$ values of less than $10 \mathrm{mg} / \mathrm{dl}$ with no sex difference or age difference, and subjects with a high level of $L p(a)$ had a higher prevalence of IHD than those with a low level.

The lowered $\mathrm{Lp}$ (a) concentrations after treatment in untreated patients with nephrotic syndrome in the present study suggests elevated $L p(a)$ synthesis of the liver. However, in view of the absence of correlation of $\mathrm{Lp}(\mathrm{a})$ with serum protein and other fractions of lipoprotein, the kinetics of $L p(a)$ in nephrotic syndrome necessitates further examination. According to Kohtoku et al, the disappearance of the broad mid-band pattern after their remission, which disc electrophoresis revealed at a high frequency in patients with nephrotic syndrome, suggests the involvement, in its appearance, of lowering of serum albumin and the leakage of protein and other substances into the urine (17). Here, $L p(a)$ was noted as a single sharp band between VLDL and LDL by disc electrophoresis. In addition, a part of the above band had a high possibility of being $\mathrm{Lp}(\mathrm{a})$.

In summary, hyperLp(a)aemia, which occurs at a high incidence in untreated patients with nephrotic syndrome was suggested to be an independent risk factor in arteriosclerotic heart disease in patients with nephrotic syndrome.

ACKNOWLEDGEMENTS: We wish to thank Professor Dr. A. Noma, Dr. M. Seishima and Dr. S. Maeda of the Department of Laboratory Medicine, Gifu University School of Medicine, for their kind cooperation in the determination Lp(a) concentrations. We also thank Dr. T. Matsui for his skillful technical assistance.

\section{REFERENCES}

1) Haba $T$, Hirai J, Saga $T$, et al. Myocardial and cerebral infarction in a 17-year-old man with hyper-Lp(a) lipoproteinemia and hypercholesterolemia associated with nephrotic syndrome due to systemic lupus erythematosus. Jpn J Med 77: 591, 1988.

2) Havel RJ, Eder EA, Bredgin JH. The distribution and chemical composition of ultracentrifugally separated lipoproteins in human serum. J Clin Invest 34: 1345, 1955.

3) Narayan KA, Narayan S, Kummerow FA. Disc electrophoresis of human lipoproteins. Nature 205: 246, 1965.

4) Goto $Y$, Akanuma $Y$, Harano $Y$, et al. Determination of serum apoproteins AI, AII, B, CII, CIII and E in normolipidemic healthy Japanese subjects: determined by SRID method. J Clin Biochem Nutr 1: 73, 1986.

5) Yamashiro M, Seishima M, Kawade M. Alterations in serum $\mathrm{Lp}$ (a) lipoprotein concentration in patients with hepatobiliary disorders. Jap J Clin Chem 16: 79, 1987.

6) Berg K. A new serum type system in man: Lp-system. Acta Pathol Microbiol Scand 59: 369, 1963.

7) Dahlen G, Berg K, Gillnas T, Ericson C. Lp(a) lipoprotein/pre $\beta_{1}$-lipoprotein in Swedish middle aged males and in patients with coronary heart disease. Clin Genet 7: 334, 1975.

8) Berg K, Dahlen G, Børresen AL. Lp(a) phenotypes, other lipoprotein parameters, and a family history of coronary heart disease in middle-aged males. Clin Genet 16: $347,1979$.

9) Rhoads GG, Morton NE, Gulbrandsen CL, Kagan A. Sinking prebeta lipoprotein and coronary heart disease in Japanese-American men in Hawaii. Am J Epidemiol 108: 350, 1978.

10) Kostner GM, Avogaro P, Cazzolato G, Marth E, Bittolo-Bon G, Quniti GB. Lipoprotein Lp(a) and the risk for myocardial infarction. Atherosclerosis 38: 51, 1981.

11) Murai A, Miyahara T, Fujimoto N, Matsuda M, Kameyama M. Lp(a) lipoprotein as a risk factor for coronary heart disease and cerebral infarction. Atherosclerosis 59: 199, 1986.

12) Armstrong VW, Cremer P, Eberle E, et al. The association between serum $\mathrm{Lp}(\mathrm{a})$ concentrations and angiographically assessed coronary atherosclerosis. 
Atherosclerosis 62: 249, 1986.

13) Dahlen GH, Guyton JR, Attar M, Farmer JA, Kautz JA, Gotto AM. Association of levels of lipoprotein Lp(a), plasma lipids, and other lipoproteins with coronary artery disease documented by angiography. Circulation 74: 758, 1986.

14) McLean JW, Tomlinson JE, Kuang W-J, et al. cDNA sequence of human apolipoprotein(a) is homologous to plasminogen. Nature 330: 132, 1987.
15) Miles LA, Fless GM, Levin EG, Scanu AM, Plow EF. A potential basis for the thrombotic risks associated with lipoprotein(a). Nature 339: 301, 1989.

16) Kawade M. Studies on the $L p(a)$ lipoprotein in Japanese. Clin Pathol 31: 391, 1983.

17) Kohtoku N, Okuda F, Shimizu K, Takagi H, Fujii Z, Kusukawa R. Serum lipoprotein abnormalities in patients with nephrotic syndrome and effect of steroid therapy. Jpn J Nephrol 31: 335, 1989. 